\title{
Complete preservation of ophiolite suite from south Andaman, India: A mineral-chemical perspective
}

\author{
Abhishek Saha ${ }^{1, *}$, Avik Dhang ${ }^{1}$, Jyotisankar Ray ${ }^{1}$, \\ Suvankar Chakraborty ${ }^{2}$ and David MoECher ${ }^{2}$ \\ ${ }^{1}$ Department of Geology, University of Calcutta, 35, Ballygunge Circular Road, Kolkata 700 019, India. \\ ${ }^{2}$ Department of Earth and Enviornmental Sciences, University of Kentucky, Lexington, Kentucky 40506, USA. \\ *e-mail: asaha.geocal@gmail.com
}

Field studies supplemented by petrographic analyses clearly reveal complete preservation of ophiolite suite from Port Blair $\left(11^{\circ} 39^{\prime} \mathrm{N}: 92^{\circ} 45^{\prime} \mathrm{E}\right)$ to Chiriyatapu $\left(11^{\circ} 30^{\prime} 24^{\prime \prime} \mathrm{N}: 92^{\circ} 42^{\prime} 30^{\prime \prime} \mathrm{E}\right)$ stretch of South Andaman. The ophiolite suite reveals serpentinite at the base which is overlain unconformably by cumulate ultramafic-mafic members with discernible cumulus texture and igneous layering. Basaltic dykes are found to cut across the cumulate ultramafic-mafic members. The succession is capped by well exposed pillow basalts interlayered with arkosic sediments. Olivine from the basal serpentinite unit are highly magnesian (Fo ${ }_{80.1-86.2}$ ). All clinopyroxene analyses from cumulate pyroxenite, cumulate gabbro and basaltic dyke are discriminated to be 'Quad' and are uniformly restricted to the diopside field. Composition of plagioclase in different lithomembers is systematically varying from calcic to sodic endmembers progressively from cumulate pyroxenite to pillow basalt through cumulate gabbro and basaltic dyke. Plagioclase phenocrysts from basaltic dyke are found to be distinctly zoned $\left(\mathrm{An}_{60.7}-\mathrm{An}_{35.3}\right)$ whereas groundmass plagioclase are relatively sodic $\left(\mathrm{An}_{33}-\mathrm{An}_{23.5}\right)$. Deduced thermobarometric data from different lithomembers clearly correspond to the observed preservation of complete ophiolite suite.

\section{Introduction}

The Andaman Ophiolite Belt marks the southern extension of the Manipur and the Burmese Arakan Yoma Belt, which is the easternmost continuation of the Tethyan Belt (figure 1). The Tethyan Belt extends from Baltic Cordillera and rift of Spain and Africa eastwards through Alps, the Denirides in Yugoslavia, through Greece, Turkey, Iran, Oman, Pakistan and the Himalayas, Burma, Andaman-Nicobar islands and Indonesia (Haldar 1984). The Andaman Ophiolite Belt belongs to a region of distinct structural and topographical belt that trends north-south and then curves eastward from Sumatra towards Java (Vohra et al 1989). Further, the Andaman islands, the central part of Burma-Java subduction complex is also believed to expose tectonostratigraphic units of accretionary prism in an outer-arc setting (Pal et al 2003). From east to west there are four such structural cum topographic zones which are:

- peripheral eastern massif of Shan Plateau, the Malay Peninsula and its western shelf, the Malacca strait and Sumatra,

- a zone of topographic lows including Irrawaddy Valley of Burma, the Andaman Basin and Mentwai through between Sumatra and Mentwai islands,

- a zone of high relief including the Arakan Yoma of Burma, the Andaman-Nicobar islands, and

- the Java Trench which probably does not extend to the latitude of the Andaman Basin.

Keywords. South Andaman; serpentinite; geothermobarometry; zoned plagioclase; idealized ophiolite. 


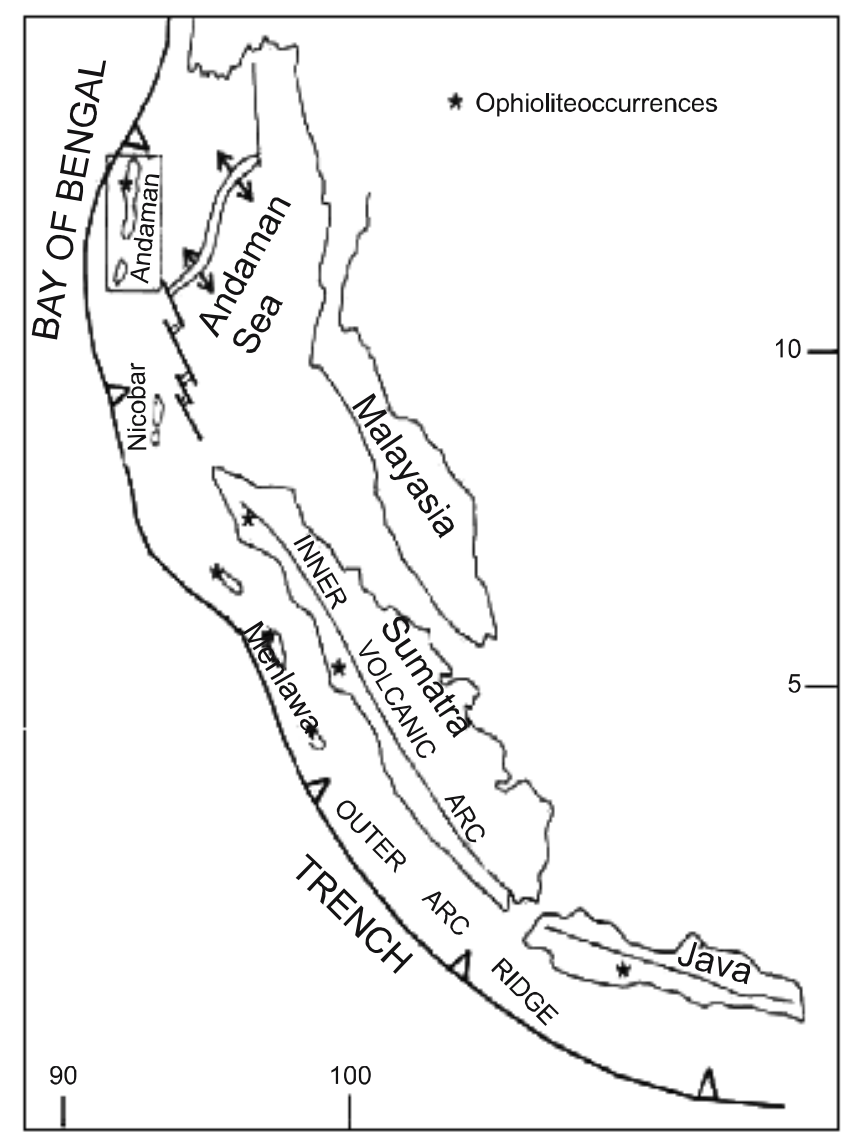

Figure 1. Tectonic elements of Indonesian Arc system and their relation with Andaman Island (after Hamilton 1978).
The overall physiographic trend of AndamanNicobar islands is the continuation of Arakan Yoma of western Burma, which is a southward trending branch of the eastern Himalayas. The Mentwai islands (south and west of Sumatra) are considered to be a southenly continuation of the AndamanNicobar trend. The Andaman-Nicobar group of islands form an arcuate chain extending for about $850 \mathrm{~km}$ bounded by latitude $6^{\circ} 45^{\prime} \mathrm{N}$ to $13^{\circ} 45^{\prime} \mathrm{N}$ and by longitude $92^{\circ} 15^{\prime} \mathrm{E}$ to $94^{\circ} 00^{\prime} \mathrm{E}$. In several parts of south Andaman, ophiolite occurrences have been described by many researchers, viz., Haldar (1984), Ray et al (1988), Vohra et al (1989), Shastry et al (2001, 2002), Srivastava et al 2004 (figure 2). In some of these literatures, this ophiolite occurrence has been reported to be a dismembered ophiolite (Srivastava et al 2004). Although, a complete preservation of ophiolite package (suite) from Port Blair $\left(11^{\circ} 39^{\prime} \mathrm{N}: 92^{\circ} 45^{\prime} \mathrm{E}\right)$ to Chiriyatapu $\left(11^{\circ} 30^{\prime} 24^{\prime \prime} \mathrm{N}\right.$ : $\left.92^{\circ} 42^{\prime} 30^{\prime \prime} \mathrm{E}\right)$ stretch has been recorded in the present investigation on the basis of field evidences and petrographic analyses. Although geochemistry and tectonic setting of Andaman ophiolites have been dealt with in detail by several researchers (Acharyya et al 1990; Pal et al 2003), mineral chemistry of constituent phases of Andaman Ophiolite Suite has not been systematically documented till date. In this view, the present contribution attempts to throw light on the mineral chemical data of the constituent



Figure 2. Geological map of the southern part of south Andaman (modified after Ray et al 1988). (1) Unclassified ophiolite, (2) basalts, (3) olistostromal argillites and ophiolite-derived clastic sediments and (4) Andaman flysch. 


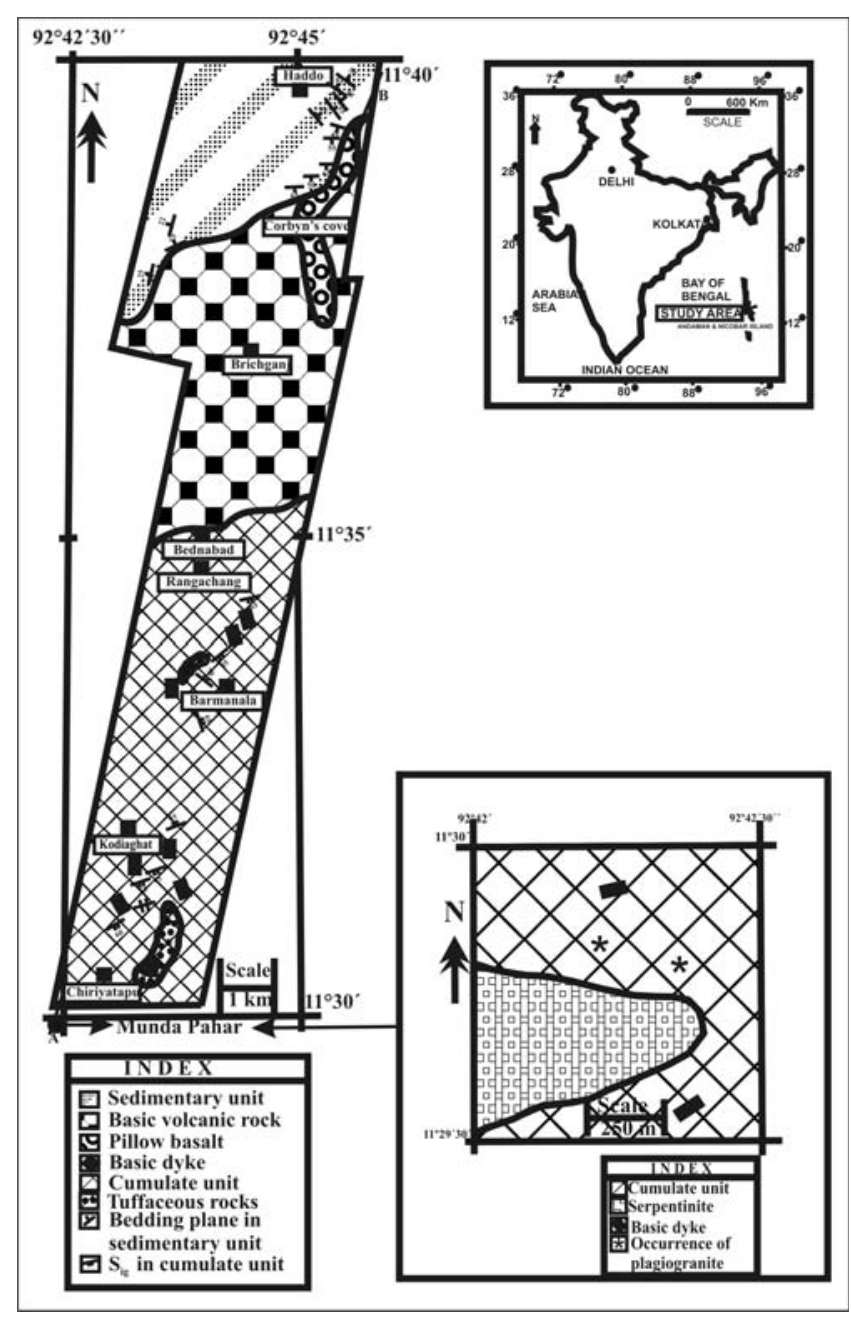

Figure 3. Geological map of the investigated area. Inset map shows the location of the study area in India map.

lithomembers from the presently investigated south Andaman Ophiolite Suite. The mineralogical data have also been utilized to decipher the P-T condition of equilibration of different lithounits of the investigated ophiolite suite.

\section{Petrography of lithomembers of ophiolite}

As per the findings of the present study, the completely preserved package of ophiolite suite has different lithomembers namely serpentinite followed upward by cumulate units, basaltic dykes which are covered by pillow basalt interlayered with arkosic sediments (figure 3). A brief lithological and petrographic description of each of the lithomembers is given below for the ready reference to the readers.

\subsection{Serpentinite}

This forms the basal portion of the ophiolite suite and is exposed in Mundapahar $\left(11^{\circ} 29.688^{\prime \prime} \mathrm{N}\right.$ : $92^{\circ} 42.381^{\prime \prime} \mathrm{E}$ ) area (figure 3). The unit is highly deformed and overlain by cumulate unit. The contact between cumulate unit and deformed serpentinite is observed in the field which corresponds to the petrological Moho (i.e., the boundary between layered peridotite and upper mantle; Wilson 1989, p. 108). This rock is melanocratic having high-to-medium specific gravity. Serpentinization occurs along two conjugate fracture planes developed in it. Most of the olivine grains are serpentinized and two sets of high-angle fractures have been formed along the olivine grains (figure 4a). Some olivine grains are present as relicts (figure 4b). Opaque minerals are formed at the juncture of fracture planes intersecting with each other.

\subsection{Cumulate unit}

The ideal sections of mafic and ultramafic cumulates are mainly located at and around the road section of Kodiaghat $\left(11^{\circ} 31^{\prime} 50^{\prime \prime} \mathrm{N}: 92^{\circ} 43^{\prime} 22^{\prime \prime} \mathrm{E}\right)-$ Bednabad $\left(11^{\circ} 34^{\prime} 52^{\prime \prime} \mathrm{N}: 92^{\circ} 43^{\prime} 18^{\prime \prime} \mathrm{E}\right)$ and Rangachang $\left(11^{\circ} 34^{\prime} 24^{\prime \prime} \mathrm{N}\right.$ : $\left.92^{\circ} 43^{\prime} 37^{\prime \prime} \mathrm{E}\right)$ area. These show a wide range of compositions. Even though the rocks are altered, they show cumulus textures which are commonly retained and are characterised by pyroxene and opaque (as cumulus phase) and poikilitic pyroxene (as intercumulus phase). Two types of cumulate varieties, viz., ultramafic and mafic cumulates are noted. Ultramafic cumulates are melanocratic, equigranular having moderately high specific gravity; serpentinization within this ultramafic cumulate occurs along number of fracture planes. This type of multi-directional fractures form mesh-like structures. Petrographically the ultramafic cumulates are represented by olivine clinopyroxenites and these are composed of clinopyroxene, olivine and opaque. Clinopyroxene grains are not serpentinized and show zoning and lamellar twining. The rock mainly shows hypidiomorphic granular texture. Petrographically, the mafic cumulate rocks correspond to gabbro. Plagioclase crystals of gabbro are partially enclosed by pyroxene grains depicting subophitic texture (figure 4c). In gabbro, preferential arrangement of mineral grains is clearly discernible which is indicative of primary cumulus texture. Plagiogranites are found to occur as discrete clots within the cumulate portion to the south of Mundapahar area (figure 3). Occurrences of those plagiogranites within cumulate rocks have earlier been reported by Vohra et al (1989) and Shastry et al (2002).

\subsection{Basaltic dykes}

In the field, the basaltic dykes (massive, dark coloured and fine-grained) are found to cross-cut 

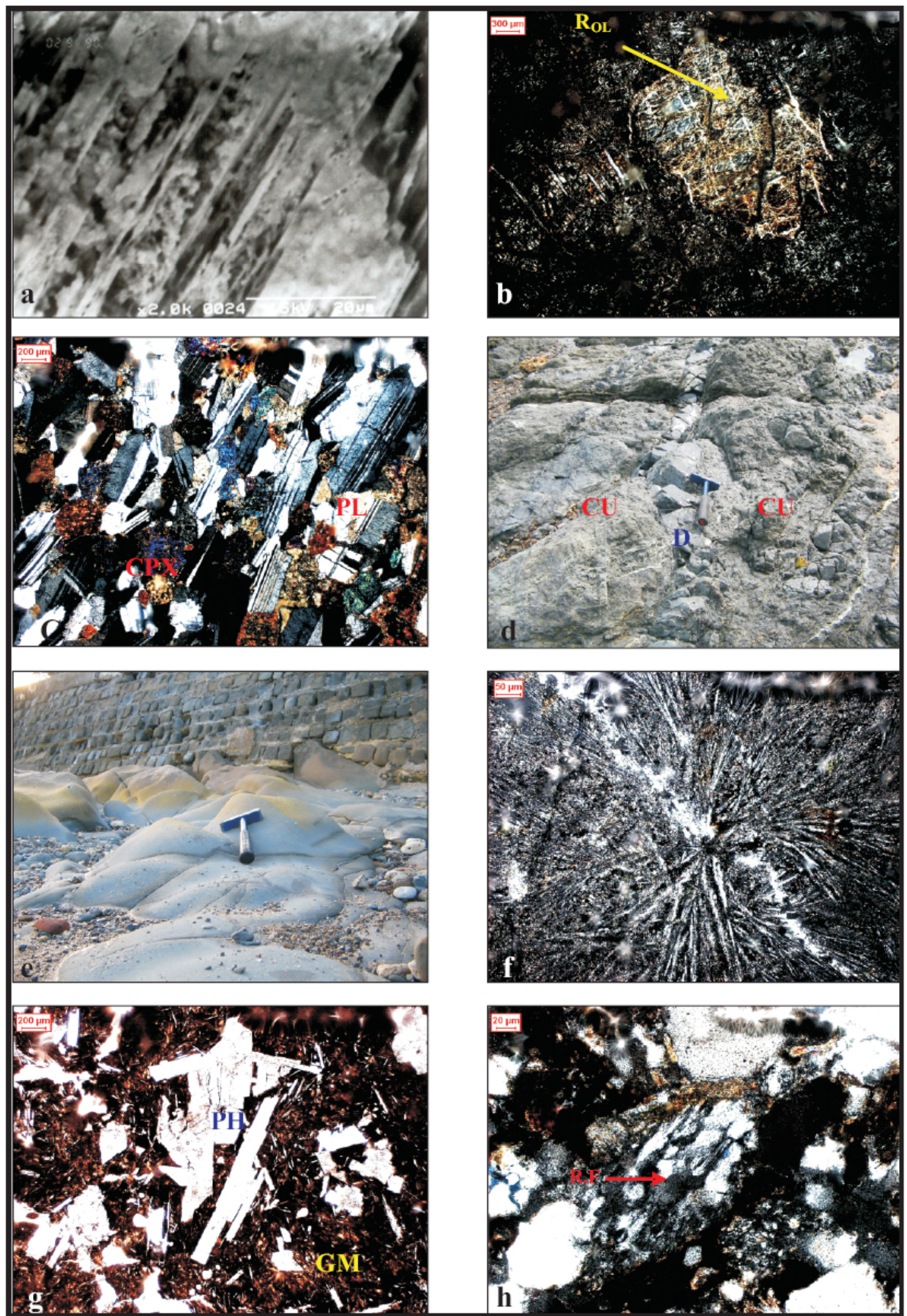

Figure 4. (a) SEM photograph showing fracture network in serpentinite (high magnification). (b) Photomicrograph showing olivine relict $\left(\mathrm{R}_{\mathrm{OL}}\right)$ in serpentinite, shape of olivine grain is preserved (Cross Polar). (c) Photomicrograph showing subophitic texture in gabbro (Cross Polar), preferential alignment of mineral grains [plagioclase (PL) and clinopyroxene (CPX)] showing primary igneous layering. (d) Field photograph showing basaltic dyke (D) cutting across the cumulate (CU) unit (looking from NW). (e) Field photograph showing pillow basalt of ophiolite suite in the present study area (looking from NE), Area: Corbyn's Cove. (f) Photomicrograph showing variolitic texture in basalt (Cross Polar). (g) Photomicrograph showing the plagioclase phenocrysts $(\mathrm{PH})$ embedded in a groundmass (GM) of plagioclase, pyroxene and volcanic glass depicting glomeroporphyritic texture in basalt (Cross Polar). (h) Photomicrograph showing basaltic rock fragment (RF) in arkosic sediments. 
Table 1. EMP analyses of olivine.

\begin{tabular}{lrrrr}
\hline Sample & \multicolumn{4}{c}{ AN 55} \\
\cline { 2 - 5 } Rock type & \multicolumn{1}{c}{$\mathrm{S}$} & $\mathrm{S}$ & \multicolumn{1}{c}{$\mathrm{S}$} & \multicolumn{1}{c}{$\mathrm{S}$} \\
\hline $\mathrm{SiO}_{2}$ & 38.88 & 38.68 & 37.56 & 38.11 \\
$\mathrm{TiO}_{2}$ & 0.05 & 0.03 & 0.06 & 0.01 \\
$\mathrm{FeO}$ & 15.56 & 13.55 & 18.6 & 14.2 \\
$\mathrm{MnO}$ & 0.32 & 0.43 & 0.23 & 0.44 \\
$\mathrm{MgO}$ & 45.29 & 47.58 & 42.1 & 46.56 \\
$\mathrm{CaO}$ & 0.64 & 0.55 & 0.72 & 0.59 \\
$\mathrm{Total}$ & 100.74 & 100.82 & 99.27 & 99.91 \\
& & $\mathbf{O}=\mathbf{4}$ & & \\
$\mathrm{Si}$ & 0.976 & 0.963 & 0.972 & 0.962 \\
$\mathrm{Ti}$ & 0.001 & 0.001 & 0.001 & 0 \\
$\mathrm{Fe}$ & 0.327 & 0.282 & 0.403 & 0.3 \\
$\mathrm{Mn}$ & 0.007 & 0.009 & 0.005 & 0.009 \\
$\mathrm{Mg}$ & 1.695 & 1.766 & 1.625 & 1.751 \\
$\mathrm{Ca}$ & 0.017 & 0.015 & 0.02 & 0.016 \\
$\mathrm{Cations}$ & 3.023 & 3.036 & 3.026 & 3.038 \\
$\mathrm{Fo}$ & 83.83 & 86.23 & 80.13 & \\
$\mathrm{Fa}$ & 16.17 & 13.77 & 19.87 & 14.63 \\
$\mathrm{Mg} \#$ & 83.8 & 86.2 & 80.1 & 85.4 \\
\hline
\end{tabular}

Note: $\mathrm{S}=$ Serpentinite.

the cumulate unit (figure 4d). Thin section studies indicate that this basaltic dyke is composed of labradoritic plagioclase $\left(\mathrm{An}_{53}-\mathrm{An}_{68}\right)$, as determined by symmetrical extinction angle, clinopyroxene and volcanic glass. Plagioclase occurs in two distinct size modes: one is larger (phenocryst) and other is relatively smaller (groundmass). Some phenocrystal plagioclase grains show zoning due to compositional variation from margin to core. Clinopyroxene grains mainly occur as prismatic phenocryst. Phenocrysts range in length from 0.4 to $0.6 \mathrm{~mm}$ while the smaller grains in the groundmass are about $0.06 \mathrm{~mm}$ in length. The overall textural pattern is defined by porphyritic texture. Groundmass shows local development of intergranular and intersertal texture.

\subsection{Pillow basalt}

The pillow basalts are best exposed at an area extending from Corbyn's cove $\left(11^{\circ} 38^{\prime} 22^{\prime \prime} \mathrm{N}\right.$ : $\left.92^{\circ} 45^{\prime} 20^{\prime \prime} \mathrm{E}\right)$ to Brichganj $\left(11^{\circ} 36^{\prime} 38^{\prime \prime} \mathrm{N}\right.$ : $92^{\circ} 44^{\prime} 15^{\prime \prime} \mathrm{E}$ ) (figure 3). This pillow basalt unit forms a carapace at the top of the ophiolite suite. In the field, pillows present are of different sizes (ranging from 0.5 to $1 \mathrm{~m}$ in diameter) and convex upward which implies the younging direction (figure 4e). These pillow basalts are fine grained and merocrystalline. Under microscope, the rock is found to be composed of plagioclase, clinopyroxene and volcanic glass. Plagioclase grains are found to be of two types: one is larger in size (phenocryst) and another is relatively smaller in size (groundmass). The phenocrysts range in length from $0.5 \mathrm{~mm}$ to $0.8 \mathrm{~mm}$ and smaller grains in the groundmass range from $0.1 \mathrm{~mm}$ to $0.15 \mathrm{~mm}$. Phenocrystal plagioclase grains are found to be albitic (determined by measuring symmetrical extinction angle). Phenocrystal pyroxene grains are larger in size and they are diopsidic. Volcanic glasses as groundmass are frequently present. These basalts are aphyric to plagioclase-phyric types with development of intergranular and variolitic texture (figure 4f). Larger plagioclase crystals are embedded in a groundmass of glass and feldspar showing porphyritic texture. Plagioclase phenocrysts are clustered with one another and floating on a groundmass of plagioclase and glass showing glomeroporphyritic texture (figure $4 \mathrm{~g}$ ). This pillow basalt was earlier described to incorporate quenched crystals of plagioclase and pyroxene (Jafri and Charan 1992).

\subsection{Sedimentary unit}

Sedimentary unit of the ophiolite suite is dominantly represented by sandstone which is the topmost unit of the investigated ophiolite suite and found to be best exposed at and around Corbyn's cove $\left(11^{\circ} 38^{\prime} 22^{\prime \prime} \mathrm{N}: 92^{\circ} 45^{\prime} 20^{\prime \prime} \mathrm{E}\right)$ and Haddo $\left(11^{\circ} 39^{\prime} 52^{\prime \prime} \mathrm{N}: 92^{\circ} 45^{\prime} 31^{\prime \prime} \mathrm{E}\right)$ area near Port Blair (figure 3). In field-exposure, the sandstone is buff coloured, massive, showing prominent preservation of bedding planes. Cross bedding is also present in sandstone. Cross laminations 


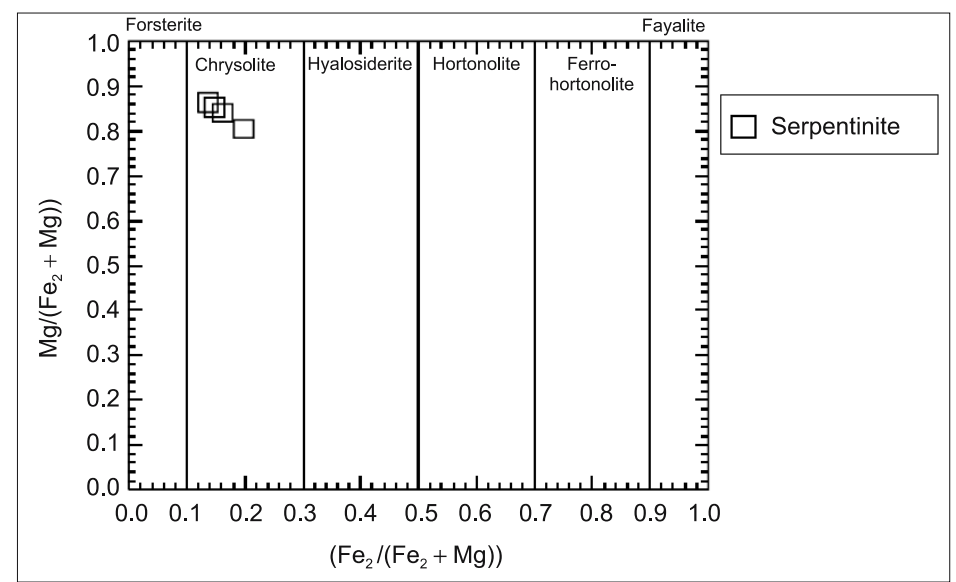

(a)

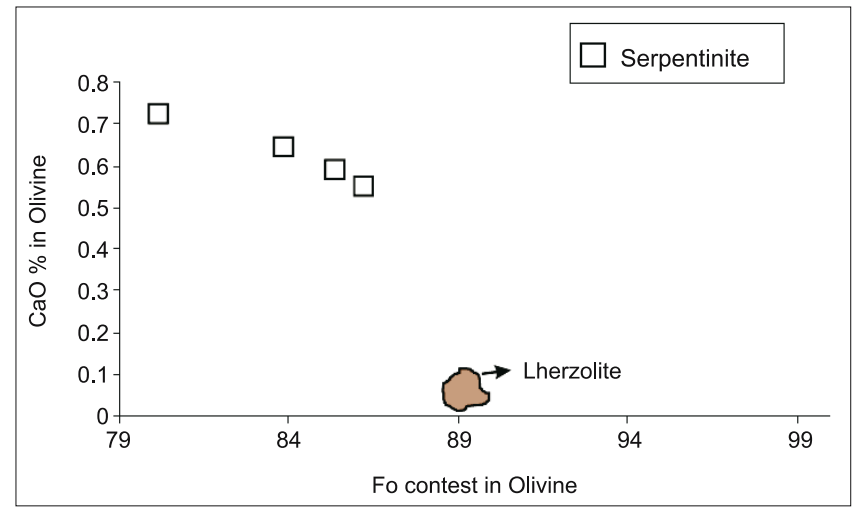

(b)

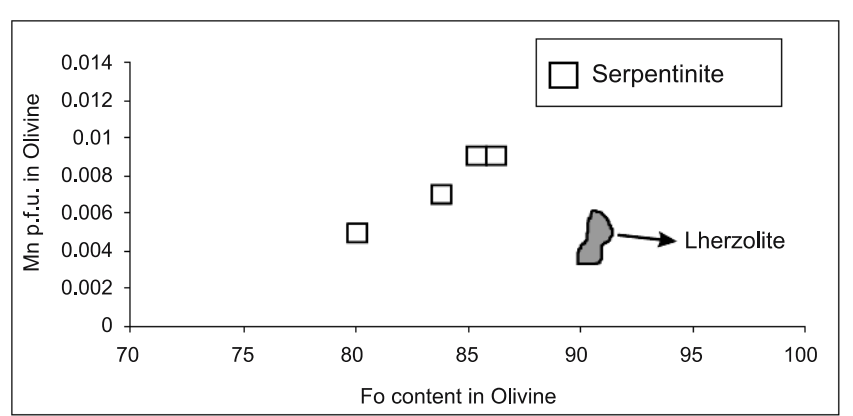

(c)

Figure 5. (a) Plot of analysed olivine compositions of investigated serpentinite from Andaman Ophiolite Suite in the olivine classificatory diagram (modified after Deer et al 1979). (b) Plot of CaO vs. Fo content in olivine of the investigated serpentinite (after Xu et al 1993). (c) Plot of Mn (a.p.f.u) vs. Fo content in olivine of the investigated serpentinite (after $\mathrm{Xu}$ et al 1993).

have been truncated by the top set at a high angle. Penecontemporaneous deformational structure like flute cast is also present in the sandstone. Framework constituents of sandstone are composed of feldspar, crystalline quartz and lithic fragment (mostly of basaltic lithology) (figure 4h). Matrix content of sandstone is relatively higher (over $10 \%$ ). These rocks (sandstones) show typical clastic texture and may be designated as arkosic wacke on the basis of modal plots on Q-R-F classificatory diagram (after Folk 1968).

\section{Mineral chemistry}

Quantitative chemical analyses of constituent mineral phases have been undertaken at the Department of Earth and Environmental Sciences, University of Kentucky, USA, using an ARL electron probe micro analyzer with computer control. A fully focused beam operating at an acceleration voltage of $15 \mathrm{kV}$ and beam current of $15 \mathrm{n} \AA$ with 1-2 $\mu \mathrm{m}$ beam diameter was applied. Synthetic as well as natural standards were used during the analyses.

\subsection{Olivine}

Olivine occurs only in the serpentinite unit, which represents the basal portion of the investigated ophiolite suite. Electron microprobe analyses of representative primary olivines have been presented in table 1. The chemical analyses of olivines show that their $\mathrm{mg}$ values range from 80.1 to 86.2 , thereby, supporting a highly magnesian character. Such a prominent magnesian character of the investigated olivines reflects a mantle restitic nature of the serpentinite unit of the Andaman ophiolite complex. The investigated olivine compositions are concentrated in the field of chrysolite, when projected into the classificatory diagram (figure 5a) (Deer et al 1979). However, the values for Fo content of analysed olivines $\left(\mathrm{Fo}_{80.1-86.2}\right)$ from the studied serpentinite are more Fe-rich than those typical of residual peridotites $\left(\mathrm{Fo}_{89-93}\right.$; Clague 1988). $\mathrm{CaO}$ in wt.\% and $\mathrm{Mn}$ in atom per 
Table 2. EMP analyses of serpentine.

\begin{tabular}{lrrrr}
\hline Sample & \multicolumn{3}{c}{ AN 55} \\
\cline { 2 - 5 } Rock type & \multicolumn{1}{c}{$\mathrm{S}$} & \multicolumn{1}{c}{$\mathrm{S}$} & \multicolumn{1}{c}{$\mathrm{S}$} & \multicolumn{1}{c}{$\mathrm{S}$} \\
\hline $\mathrm{SiO}_{2}$ & 37.01 & 40.12 & 40.55 & 38.12 \\
$\mathrm{TiO}_{2}$ & 0.19 & 0.38 & 0.26 & 0.15 \\
$\mathrm{Al}_{2} \mathrm{O}_{3}$ & 2.86 & 1.89 & 2.12 & 1.95 \\
$\mathrm{FeO}$ & 14.37 & 20.36 & 21.02 & 15.22 \\
$\mathrm{MnO}$ & 0.85 & 0.55 & 0.58 & 0.74 \\
$\mathrm{MgO}$ & 39.83 & 31.23 & 29.98 & 40.12 \\
$\mathrm{CaO}$ & 3.29 & 4.08 & 3.99 & 3.19 \\
$\mathrm{Na}{ }_{2} \mathrm{O}$ & 0.95 & 1.12 & 1.25 & 0.96 \\
$\mathrm{~K}$ & $\mathrm{O}$ & 0.71 & 0.74 & 0.68 \\
$\mathrm{Total}$ & 0.67 & 100.44 & 100.49 & 101.13 \\
& 100.02 & $\mathbf{O}=\mathbf{7}$ & & \\
$\mathrm{Si}$ & & 1.822 & 1.844 & 1.69 \\
$\mathrm{Al}$ & 1.657 & 0.101 & 0.114 & 0.102 \\
$\mathrm{Ti}$ & 0.151 & 0.013 & 0.009 & 0.005 \\
$\mathrm{Fe}$ & 0.006 & 0.773 & 0.799 & 0.564 \\
$\mathrm{Mn}$ & 0.538 & 0.021 & 0.022 & 0.028 \\
$\mathrm{Mg}$ & 0.032 & 2.115 & 2.032 & 2.652 \\
$\mathrm{Ca}$ & 2.658 & 0.199 & 0.194 & 0.152 \\
$\mathrm{Na}$ & 0.158 & 0.099 & 0.11 & 0.083 \\
$\mathrm{~K}$ & 0.082 & 0.041 & 0.043 & 0.038 \\
$\mathrm{Cations}$ & 0.038 & 5.184 & 5.167 & 5.314 \\
$\mathrm{Fo}$ & 5.32 & 0.73 & 0.72 & 0.82 \\
$\mathrm{Fa}$ & 0.83 & 0.27 & 0.28 & 0.18 \\
\hline $\mathrm{Not}$ & 0.17 & & &
\end{tabular}

Note: $\mathrm{S}=$ Serpentinite.

formula unit of the analysed olivines have been plotted against respective Fo content in biaxial diagrams (figure 5b and 5c, after $\mathrm{Xu}$ et al 1993). In figure 5(b), the analysed olivine compositions plot away from the lherzolite field of Group I peridotite (Frey and Prinz 1978; Xu et al 1993). The secluded nature for the data-plots of olivine compositions (figure 5c) is also very distinct with respect to lherzolite field (Xu et al 1993) in the Fo content vs. Mn (apfu) biaxial diagram.

\subsection{Serpentine}

Serpentine marks an important mineral phase in the investigated serpentinite unit. Serpentine grains are formed secondarily after olivine. Electron probe analyses of constituent serpentine grains from serpentinite $(\mathrm{S})$ are given in table 2 . The data of analysed serpentine grains depict a prominent enrichment in magnesium and iron when compared to that of primary olivine (table 1).

\subsection{Pyroxene}

The data obtained from sixteen pyroxene analyses, representing three lithomembers of the investigated ophiolite suite, namely cumulate pyroxenite
(CP), cumulate gabbro (CG) and basaltic dyke (BD) have been furnished in table 3. The mineralchemical analyses (table 3 ) indicate nearly uniform pyroxene compositions in all the three lithotypes. Consideration of the analysed pyroxenes has been made in order to classify them in a systematic manner on the basis of 'Q' and ' $\mathrm{J}$ ' relations (Morimoto et al 1988). As per ' $Q$ ' and 'J' relations (where $\mathrm{Q}=\mathrm{Ca}+\mathrm{Mg}+\mathrm{Fe}$ and $\mathrm{J}=2 \mathrm{Na}$ ), when the compositions of analysed clinopyroxenes are plotted in Q-J classificatory diagram (Morimoto 1989) (figure 6a), the plots are found to occupy the ' $Q$ ' (Quad) field and therefore may be designated as Quad pyroxenes. The investigated pyroxene compositions are next projected onto Wo-En-Fs triangle (Morimoto et al 1988) (figure 6b), where all the data-plots occupy the diopside field and hence indicate nearly uniform compositional range. Mg number of the analyzed pyroxenes ranges from 0.86 to 0.92 in cumulate pyroxenites, 0.82 to 0.89 in cumulate gabbro and in basaltic dykes mg number of pyroxene is 0.83 . The high mg number of presently investigated pyroxenes is consistent with pyroxene compositions in other ophiolite complexes and island arcs (De Bari and Coleman 1989; Bonev and Stampfli 2009). In cumulate pyroxenite, Ca content of pyroxene shows an increasing trend with respect 
to increasing mg number while in cumulate gabbro Ca content of pyroxene shows a declining trend with rising $\mathrm{mg}$ number. The low $\mathrm{Na}_{2} \mathrm{O}$ content of the analysed pyroxenes indicates a sub-alkaline nature of the parental magma and a relatively low pressure of crystallization (Bonev and Stampfli 2009). The low Ti content of the clinopyroxene possibly reflects the degree of depletion of the mantle source (Pearce and Norry 1979). Relevant pyroxene compositions can be effectively used to discriminate tectonic setting of the presently studied ophiolite suite and delineate parental magma types. As for example, pyroxene compositions when referred to M1Ti vs. M2 Ca biaxial diagram (Leterrier et al 1982), the data-plots are found to be concentrated in the orogenic field (figure 6c). Further, a plot of pyroxene compositions in Ti vs. $(\mathrm{Ca}+\mathrm{Na})$ diagram (Leterrier et al 1982; Salavati
2008) suggests tholeiitic and calc-alkaline character for the parental basaltic magma (figure 6d). Moreover, the projection of analysed pyroxene compositions on $\mathrm{TiO}_{2}$ vs. $\mathrm{Al}_{2} \mathrm{O}_{3}$ diagram (Le Bas 1962) distinctly reflects a calc-alkaline nature of the parental magma (figure 6e). Thus, the pyroxene chemistry is clearly indicative of an orogenic setting and calc-alkaline parentage of the Andaman Ophiolite Belt as suggested earlier by researchers like Acharyya et al (1990) and Pal et al (2003).

\subsection{Plagioclase}

Altogether twenty-five analyses of plagioclase from four constituent lithomembers of the Andaman Ophiolite Suite, namely, cumulate pyroxenite (CP), cumulate gabbro (CG), basaltic dyke (BD) and pillow basalt $(\mathrm{PB})$ have been furnished

Table 3. EMP analyses of pyroxene.

\begin{tabular}{|c|c|c|c|c|c|c|}
\hline \multirow{2}{*}{$\begin{array}{l}\text { Sample } \\
\text { Rock type }\end{array}$} & \multicolumn{6}{|c|}{ AN 45} \\
\hline & $\mathrm{CP}$ & $\mathrm{CP}$ & $\mathrm{CP}$ & $\mathrm{CP}$ & $\mathrm{CP}$ & $\mathrm{CP}$ \\
\hline $\mathrm{SiO}_{2}$ & 52.01 & 53.05 & 53.12 & 53.14 & 52.34 & 53.44 \\
\hline $\mathrm{TiO}_{2}$ & 0.16 & 0.16 & 0.29 & 0.35 & 0.08 & 0.27 \\
\hline $\mathrm{Al}_{2} \mathrm{O}_{3}$ & 0.66 & 0.69 & 1.16 & 1.23 & 0.34 & 1.1 \\
\hline $\mathrm{FeO}$ & 3.55 & 4.75 & 4.15 & 4.15 & 3.3 & 4.4 \\
\hline $\mathrm{MnO}$ & 0.13 & 0.13 & 0.15 & 0.2 & 0.22 & 0.19 \\
\hline $\mathrm{MgO}$ & 19.07 & 17.04 & 18.28 & 17.77 & 18.74 & 17.77 \\
\hline $\mathrm{CaO}$ & 23.69 & 23.89 & 23.48 & 23.08 & 23.89 & 23.38 \\
\hline $\mathrm{Na}_{2} \mathrm{O}$ & 0.1 & 0.1 & 0.11 & 0.08 & 0.09 & 0.14 \\
\hline $\mathrm{K}_{2} \mathrm{O}$ & 0 & 0 & 0.01 & 0 & 0.02 & 0 \\
\hline Total & 99.37 & 99.81 & 100.75 & 100.00 & 99.02 & 100.69 \\
\hline \multicolumn{7}{|c|}{$O=6$} \\
\hline TSi & 1.891 & 1.942 & 1.915 & 1.935 & 1.912 & 1.933 \\
\hline $\mathrm{TAl}$ & 0.028 & 0.03 & 0.049 & 0.053 & 0.015 & 0.047 \\
\hline $\mathrm{M} 1 \mathrm{Al}$ & 0 & 0 & 0 & 0 & 0 & 0 \\
\hline M1Ti & 0.004 & 0.004 & 0.008 & 0.01 & 0.002 & 0.007 \\
\hline M1Fe2 & 0 & 0.066 & 0.01 & 0.026 & 0 & 0.034 \\
\hline $\mathrm{M} 1 \mathrm{Mg}$ & 0.996 & 0.93 & 0.983 & 0.964 & 0.998 & 0.958 \\
\hline $\mathrm{M} 2 \mathrm{Mg}$ & 0.038 & 0 & 0 & 0 & 0.023 & 0 \\
\hline $\mathrm{M} 2 \mathrm{Fe} 2$ & 0.108 & 0.08 & 0.116 & 0.1 & 0.101 & 0.099 \\
\hline M2Mn & 0.004 & 0.004 & 0.005 & 0.006 & 0.007 & 0.006 \\
\hline $\mathrm{M} 2 \mathrm{Ca}$ & 0.923 & 0.937 & 0.907 & 0.9 & 0.935 & 0.906 \\
\hline $\mathrm{M} 2 \mathrm{Na}$ & 0.007 & 0.007 & 0.008 & 0.006 & 0.006 & 0.01 \\
\hline M2K & 0 & 0 & 0 & 0 & 0.001 & 0 \\
\hline Sum_cat & 4 & 4 & 4 & 4 & 4 & 4 \\
\hline $\mathrm{Q}$ & 2.065 & 2.013 & 2.015 & 1.991 & 2.057 & 1.997 \\
\hline $\mathrm{J}$ & 0.014 & 0.014 & 0.015 & 0.011 & 0.013 & 0.02 \\
\hline WO & 44.616 & 46.47 & 44.918 & 45.076 & 45.32 & 45.232 \\
\hline EN & 49.972 & 46.118 & 48.658 & 48.289 & 49.464 & 47.834 \\
\hline FS & 5.412 & 7.412 & 6.424 & 6.635 & 5.216 & 6.935 \\
\hline $\mathrm{Mg} \#$ & 0.91 & 0.86 & 0.89 & 0.88 & 0.91 & 0.88 \\
\hline
\end{tabular}


Table 3. (Continued).

\begin{tabular}{|c|c|c|c|c|c|c|c|c|}
\hline \multirow{2}{*}{$\begin{array}{l}\text { Sample } \\
\text { Rock type }\end{array}$} & \multicolumn{2}{|c|}{ AN 79} & \multicolumn{6}{|c|}{ AN 69} \\
\hline & $\mathrm{CP}$ & $\mathrm{CP}$ & CG & $\mathrm{CG}$ & $\mathrm{CG}$ & $\mathrm{CG}$ & $\mathrm{CG}$ & CG \\
\hline $\mathrm{SiO}_{2}$ & 52.34 & 53.29 & 54.1 & 53.53 & 53.76 & 54.22 & 53.42 & 54.55 \\
\hline $\mathrm{TiO}_{2}$ & 0.08 & 0.14 & 0.05 & 0.15 & 0.09 & 0.33 & 0.29 & 0.35 \\
\hline $\mathrm{Al}_{2} \mathrm{O}_{3}$ & 0.34 & 0.46 & 0.49 & 0.74 & 1.2 & 0.97 & 1.36 & 1.3 \\
\hline $\mathrm{FeO}$ & 3.3 & 2.89 & 6.35 & 5.97 & 5.52 & 5.91 & 4.45 & 3.95 \\
\hline $\mathrm{MnO}$ & 0.19 & 0.09 & 0.24 & 0.19 & 0.11 & 0.24 & 0.15 & 0.2 \\
\hline $\mathrm{MgO}$ & 17.74 & 18.02 & 16.47 & 16.54 & 16.71 & 15.91 & 18.54 & 18.44 \\
\hline $\mathrm{CaO}$ & 25.49 & 26.17 & 23.35 & 23.22 & 21.72 & 23.89 & 23.11 & 22.95 \\
\hline $\mathrm{Na}_{2} \mathrm{O}$ & 0.09 & 0.06 & 0.24 & 0.26 & 0.42 & 0.15 & 0.11 & 0.08 \\
\hline $\mathrm{K}_{2} \mathrm{O}$ & 0.02 & 0 & 0 & 0 & 0 & 0 & 0.01 & 0 \\
\hline Total & 99.59 & 101.12 & 101.29 & 100.60 & 99.53 & 101.62 & 101.44 & 101.82 \\
\hline \multicolumn{9}{|c|}{$O=6$} \\
\hline TSi & 1.909 & 1.913 & 1.963 & 1.952 & 1.974 & 1.965 & 1.913 & 1.947 \\
\hline $\mathrm{TAl}$ & 0.015 & 0.019 & 0.021 & 0.032 & 0.026 & 0.035 & 0.057 & 0.053 \\
\hline M1Al & 0 & 0 & 0 & 0 & 0.026 & 0.007 & 0 & 0.002 \\
\hline M1Ti & 0.002 & 0.004 & 0.001 & 0.004 & 0.002 & 0.009 & 0.008 & 0.009 \\
\hline $\mathrm{M} 1 F e_{2}$ & 0.033 & 0.032 & 0.108 & 0.097 & 0.057 & 0.125 & 0.003 & 0.007 \\
\hline $\mathrm{M} 1 \mathrm{Mg}$ & 0.965 & 0.964 & 0.891 & 0.899 & 0.915 & 0.86 & 0.99 & 0.981 \\
\hline $\mathrm{M} 2 \mathrm{Mg}$ & 0 & 0 & 0 & 0 & 0 & 0 & 0 & 0 \\
\hline $\mathrm{M}_{2} \mathrm{Fe}_{2}$ & 0.067 & 0.055 & 0.085 & 0.085 & 0.112 & 0.054 & 0.131 & 0.111 \\
\hline M2Mn & 0.006 & 0.003 & 0.007 & 0.006 & 0.003 & 0.007 & 0.005 & 0.006 \\
\hline $\mathrm{M} 2 \mathrm{Ca}$ & 0.996 & 1.006 & 0.908 & 0.907 & 0.854 & 0.928 & 0.887 & 0.878 \\
\hline $\mathrm{M} 2 \mathrm{Na}$ & 0.006 & 0.004 & 0.017 & 0.018 & 0.03 & 0.011 & 0.008 & 0.006 \\
\hline M2K & 0.001 & 0 & 0 & 0 & 0 & 0 & 0 & 0 \\
\hline Sum_cat & 3.999 & 4 & 4 & 4 & 4 & 4 & 4 & 4 \\
\hline Q & 2.061 & 2.057 & 1.991 & 1.988 & 1.939 & 1.967 & 2.009 & 1.977 \\
\hline $\mathrm{J}$ & 0.013 & 0.008 & 0.034 & 0.037 & 0.06 & 0.021 & 0.015 & 0.011 \\
\hline WO & 48.186 & 48.852 & 45.417 & 45.49 & 43.998 & 47 & 44.02 & 44.264 \\
\hline EN & 46.661 & 46.804 & 44.573 & 45.086 & 47.098 & 43.551 & 49.137 & 49.485 \\
\hline $\mathrm{FS}$ & 5.153 & 4.344 & 10.01 & 9.423 & 8.904 & 9.449 & 6.842 & 6.251 \\
\hline $\mathrm{Mg} \#$ & 0.91 & 0.92 & 0.82 & 0.83 & 0.84 & 0.83 & 0.88 & 0.89 \\
\hline
\end{tabular}

Note: $\mathrm{CP}=$ Cumulate pyroxenite; $\mathrm{CG}=$ Cumulate gabbro.

in table 4. When the plagioclase compositions are projected onto Or-Ab-An triangular diagram (figure 7), the data-plots depict a wide compositional spectrum. A closer examination of the plotted plagioclase compositions reveals that the maximum anorthite component of plagioclase from investigated cumulate pyroxenite $(\mathrm{CP})$ shoots up to $\mathrm{An}_{99.7}$. Plagioclase from cumulate gabbro (CG) belongs to bytownite species with anorthite component ranging between 77.7 and 87.8 while two plagioclase analyses correspond to the andesine variety with anorthite component ranging between 31.5 and 33.1 and this refers to intercumulus plagioclase. Plagioclase analyses of basaltic dyke (BD) are available for both phenocrystal and groundmass phases (table 4). The phenocrysts range in composition from $\mathrm{An}_{60.7}$ to $\mathrm{An}_{35.3}$ (labradorite-andesine) which reflects normal zoning as a consequence of reaction failure in the magma chamber. Groundmass plagioclases are relatively sodic $\left(\mathrm{An}_{33}-\mathrm{An}_{23.5}\right)$ and correspond to calcic oligoclase to sodic andesine (figure 7). Analysed plagioclase of pillow basalt (PB) (table 4) is found to be distinctly albite-oligoclase $\left(\mathrm{An}_{7.3^{-}}\right.$ $\left.\mathrm{An}_{15.8}\right)$ as it is expected for pillow basalts of different well-documented ophiolite suites. The sufficiently sodic chemistry of plagioclase in the pillow basalt signifies its spilitic nature. The high An contents of plagioclase in cumulate pyroxenite and cumulate gabbro are comparable to that of plagioclase in arc-related igneous rocks (Dupuy et al 1982; Beard 1986; De Bari and Coleman 1989), reflecting significant dissolved water contents and high $\mathrm{Ca} /(\mathrm{Ca}+\mathrm{Na})$ ratios (Arculus and Wills 1980; Sisson and Grove 1993; Bonev and Stampfli 2009). 
Table 3. (Continued).

\begin{tabular}{|c|c|c|c|}
\hline \multirow{2}{*}{$\begin{array}{l}\text { Sample } \\
\text { Rock type }\end{array}$} & \multicolumn{3}{|c|}{ AN 69A } \\
\hline & $\mathrm{BD}$ & $\mathrm{BD}$ & $\mathrm{BD}$ \\
\hline $\mathrm{SiO}_{2}$ & 54.53 & 54.81 & 54.22 \\
\hline $\mathrm{TiO}_{2}$ & 0.16 & 0.06 & 0.03 \\
\hline $\mathrm{Al}_{2} \mathrm{O}_{3}$ & 0.34 & 0.24 & 0.37 \\
\hline $\mathrm{FeO}$ & 5.83 & 5.73 & 5.91 \\
\hline $\mathrm{MnO}$ & 0.28 & 0.25 & 0.24 \\
\hline $\mathrm{MgO}$ & 15.6 & 15.7 & 15.91 \\
\hline $\mathrm{CaO}$ & 24.4 & 24.26 & 23.89 \\
\hline $\mathrm{Na}_{2} \mathrm{O}$ & 0.18 & 0.17 & 0.15 \\
\hline $\mathrm{K}_{2} \mathrm{O}$ & 0 & 0 & 0 \\
\hline Total & 101.32 & 101.22 & 100.72 \\
\hline \multicolumn{4}{|c|}{$O=6$} \\
\hline TSi & 1.985 & 1.995 & 1.982 \\
\hline TAl & 0.015 & 0.005 & 0.016 \\
\hline M1Al & 0 & 0.006 & 0 \\
\hline M1Ti & 0.004 & 0.002 & 0.001 \\
\hline $\mathrm{M} 1 F e_{2}$ & 0.149 & 0.14 & 0.132 \\
\hline $\mathrm{M} 1 \mathrm{Mg}$ & 0.846 & 0.852 & 0.867 \\
\hline $\mathrm{M} 2 \mathrm{Mg}$ & 0 & 0 & 0 \\
\hline $\mathrm{M}_{2} \mathrm{Fe}_{2}$ & 0.028 & 0.034 & 0.048 \\
\hline M2Mn & 0.009 & 0.008 & 0.007 \\
\hline $\mathrm{M} 2 \mathrm{Ca}$ & 0.951 & 0.946 & 0.936 \\
\hline $\mathrm{M} 2 \mathrm{Na}$ & 0.013 & 0.012 & 0.011 \\
\hline M2K & 0 & 0 & 0 \\
\hline Sum_cat & 4 & 4 & 4 \\
\hline $\mathrm{Q}$ & 1.975 & 1.973 & 1.983 \\
\hline $\mathrm{J}$ & 0.025 & 0.024 & 0.021 \\
\hline WO & 47.958 & 47.779 & 47 \\
\hline EN & 42.663 & 43.023 & 43.551 \\
\hline FS & 9.379 & 9.198 & 9.449 \\
\hline $\mathrm{Mg} \#$ & 0.83 & 0.83 & 0.83 \\
\hline
\end{tabular}

Note: BD = Basaltic dyke.

\section{Geothermobarometry}

The relevant mineral-chemical data of constituent phases can be successfully applied for geothermobarometric estimations.

\subsection{Geothermometry}

On consideration of the available mineralogical assemblage of constituent lithomembers of the Andaman Ophiolite Suite, pyroxene thermometry appears to be most applicable.

An effective method of determining temperature with the help of pyroxene compositions was proposed by Lindsley (1983). The procedure involves simple recalculation of the analysed pyroxene compositions in terms of several end-member molecules and subsequent plotting of those recalculated molecules in terms of experimentally determined pyroxene thermometer contours. The investigated pyroxene compositions when projected into the diagram advocated by Lindsley (1983) reveal a wide range of temperature $\left(\sim 500^{\circ} \mathrm{C}-1100^{\circ} \mathrm{C}\right)$ (figure 8).

\subsection{Geobarometry}

Geobarometric estimates in the present study were confined to clinopyroxene barometry based on method proposed by Ashchepkov (2009). The deduced values (table 5) also reveal a closely comparable pressure for both cumulate pyroxenite $(\mathrm{CP})$ and cumulate gabbro (CG) (average pressure values $7.01 \mathrm{~Kb}$ and $8.58 \mathrm{~Kb}$ respectively) corresponding to a depth of crystallization of $\sim 21-27 \mathrm{~km}$. The basaltic dyke (BD) on the other hand reveals an average pressure of $4.57 \mathrm{~Kb}$ which corresponds to a much shallower intrusion.

\section{Discussion and remarks}

Although occurrences of different types of ultramafic rocks around Port Blair of south Andaman have long been known, no systematic description of those rocks in the light of ophiolite-tectonics was available. As per the existing previous literature, the stretch between Port Blair and Chiriyatapu has been designated as 'unclassified ophiolite' and hence, details of the ophiolite rock units have not been delineated so far. On the other hand, segmented recognition and descriptions of different rock units namely basalts, argillites and ultramafic plutonic rocks led to think some worker 'preservation of dismembered ophiolite' (Srivastava et al 2004). In order to describe an ophiolite succession as a complete one, recognition of different mantle ultramafic units like harzburgite, lherzolite, dunite is essential (Coleman 1977; Nicolas 1989). But whether the preservation of the mantle ultramafic units (harzburgite, lherzolite, dunite, etc.) will be intact or not depends largely on the degree of serpentinization and degree of mantle melting (Muntener and Manatschal 2006). In many cases, mantle peridotites are found to be suffered by pervasive serpentinization accompanying deformational fabric (Hebert et al 2006). This extensive serpentinization of peridotite might have retained relicts of orthopyrxene and olivine. Rockdeformation experiments clearly indicate that serpentinization can strongly influence the strength and tectonics of the oceanic lithosphere especially the upper mantle part. Such serpentinization is a common phenomenon along slow spreading ridge segments (Escartin et al 1997). In addition to serpentinization, pervasive melt-percolation reaction plays a very important role on the original refractory harzburgite mantle material (Seyler 

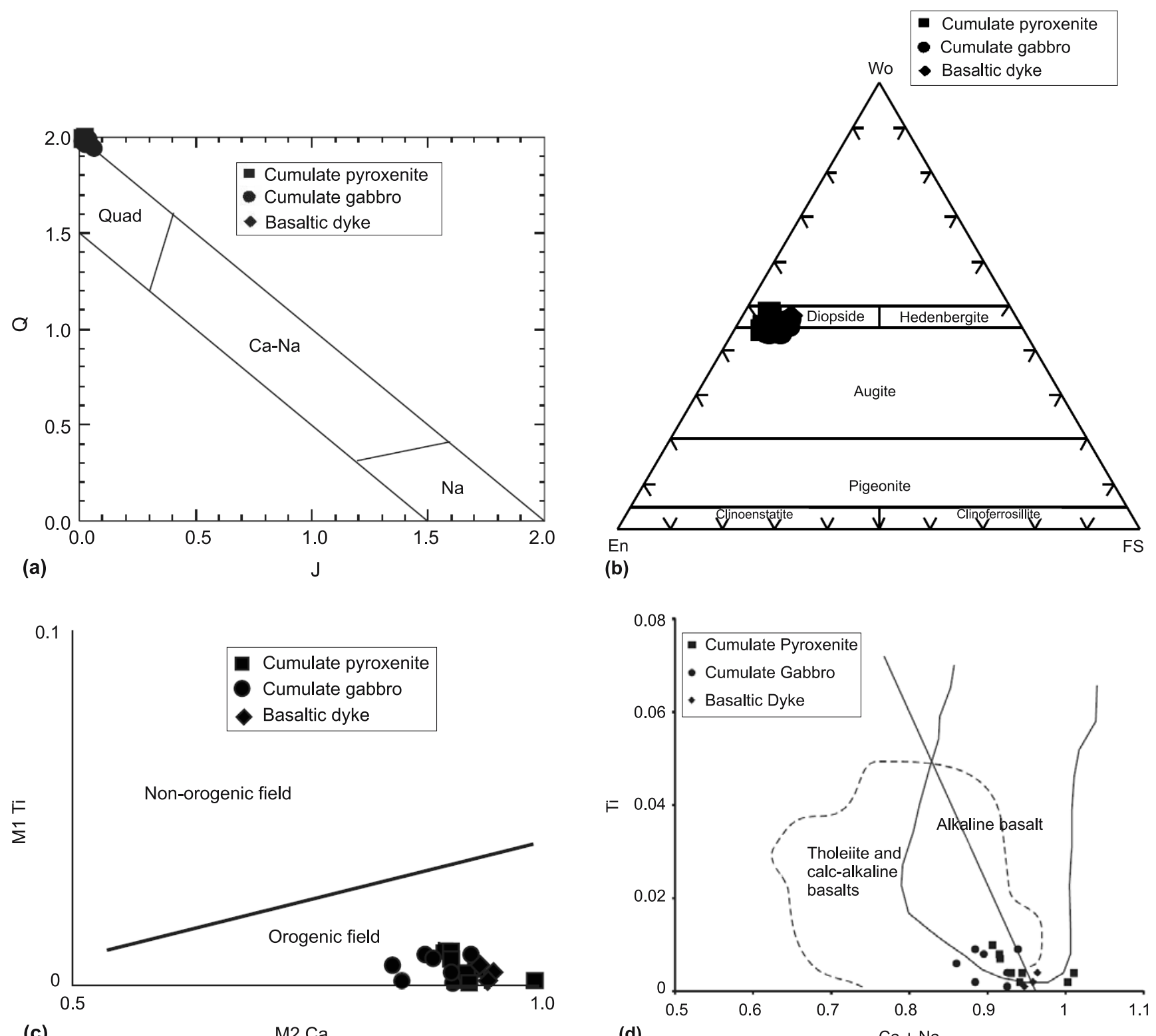

(b)
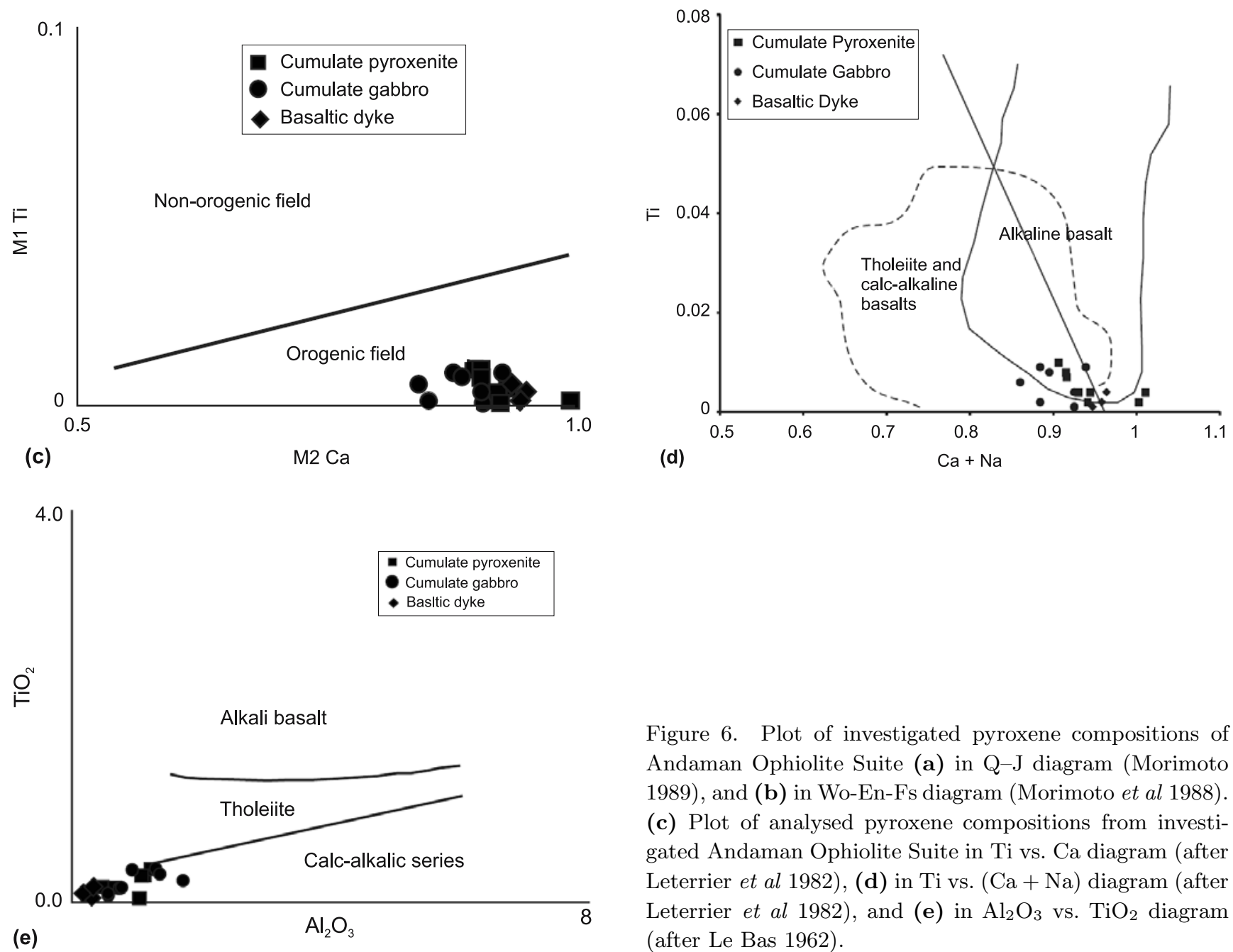

Figure 6. Plot of investigated pyroxene compositions of Andaman Ophiolite Suite (a) in Q-J diagram (Morimoto 1989), and (b) in Wo-En-Fs diagram (Morimoto et al 1988). (c) Plot of analysed pyroxene compositions from investigated Andaman Ophiolite Suite in Ti vs. Ca diagram (after Leterrier et al 1982), (d) in Ti vs. (Ca $+\mathrm{Na}$ ) diagram (after Leterrier et al 1982), and (e) in $\mathrm{Al}_{2} \mathrm{O}_{3}$ vs. $\mathrm{TiO}_{2}$ diagram (after Le Bas 1962). 


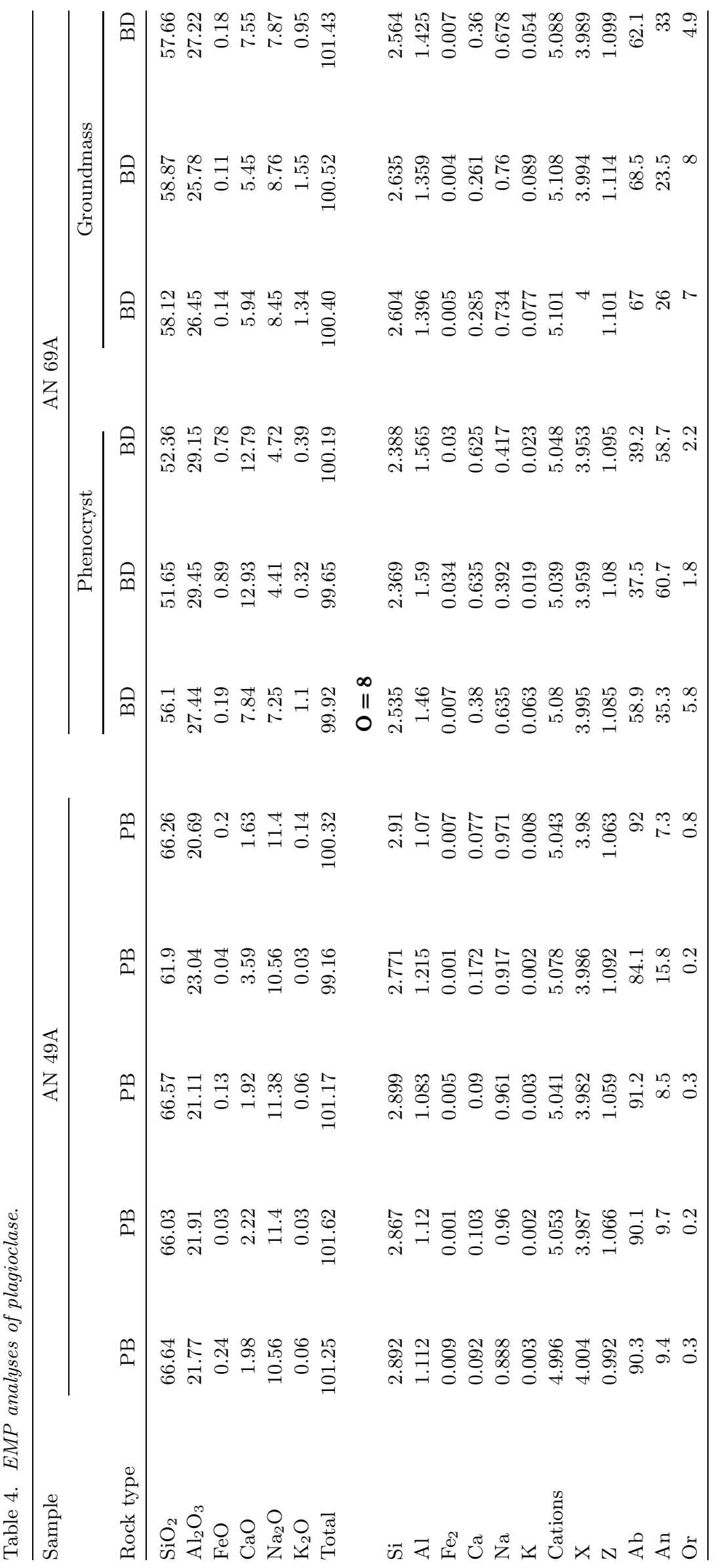




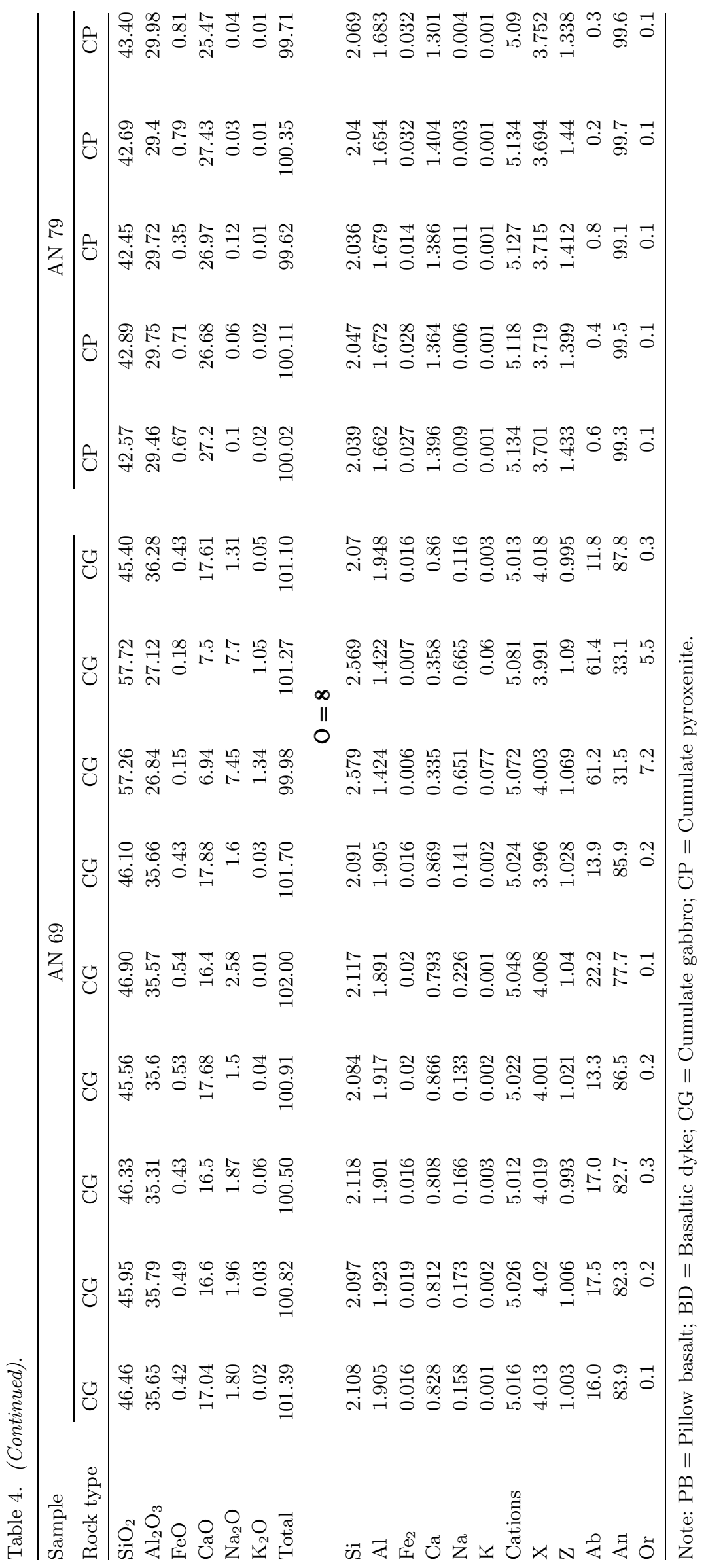


et al 2007). Detailed studies of microstructures of harzburgite show that they have extensively reacted with a pervading intergranular melt giving rise to crystallization of olivine, clinopyroxene and spinel at the expense of orthopyroxene and the ultra-depleted compositions of the mantle material were attended through melt reequilibration with residual harzburgite. The harzburgite mantle material is a residue of partial melting where the generated melt is in equilibrium with clinopyroxene. Moreover, in many cases, harzburgites are found to experience higher degree of partial melting than abyssal peridotite (Akihiro and Shoji 2006).

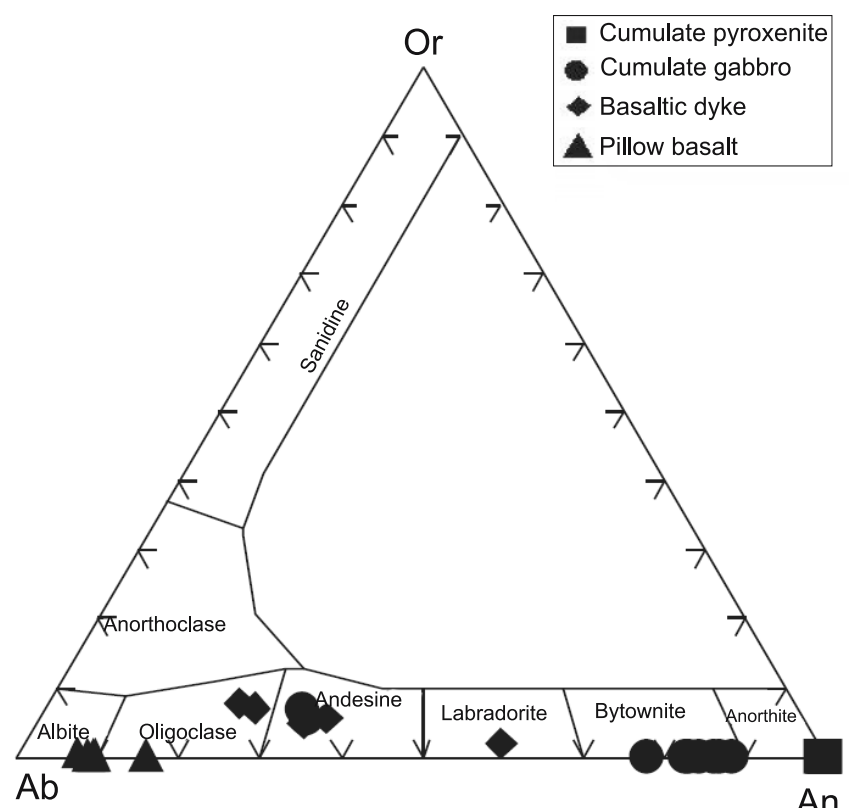

Figure 7. Projection of investigated plagioclase compositions in Or-Ab-An triangular diagram.
Table 5. Geobarometric data (after Ashchepkov 2009) with respect to pyroxene chemistry.

\begin{tabular}{cccc}
\hline $\begin{array}{c}\text { Specimen } \\
\text { no. }\end{array}$ & Rock type & $\begin{array}{c}\text { Pressure } \\
\text { in Kb }\end{array}$ & $\begin{array}{c}\text { Average } \\
\text { pressure } \\
\text { in Kb }\end{array}$ \\
\hline AN 45 & Cumulate & 7.33 & 7.01 \\
& pyroxenite & 5.48 & \\
& & 7.7 & \\
AN 79 & & 8.42 & \\
& & 5.43 & \\
AN 69 & Cumulate gabbro & 7.7 & \\
& & 7.63 & 8.58 \\
& & 7.46 & \\
& & 6.8 & \\
& & 9.42 & \\
AN 69A & & 10.09 & \\
& & 3.83 & 4.57 \\
& & 4.41 & \\
\hline
\end{tabular}

As a testimony of this contention, the Newfoundland harzburgite can be modelled as a residue after extraction of about 20\% melting (Muntener and Manatschal 2006). In some cases, however, partial melting up to $30 \%$ has been recorded to explain the depleted mantle harzburgite and dunite (Uysal et al 2007).

In general ultramafic tectonites of ophiolite sequences can be easily linked to uplifted sections of upper mantle having evidenced varying degrees of partial melting and melt infiltration. Troodos ophiolite is located near a fossil ridge-transform interaction where a sequence of heavily serpentinized rocks occurs adjacent to a major axis parallel fault (Nuriel et al 2009). The pronounced effects of serpentinization in the basal ophiolite

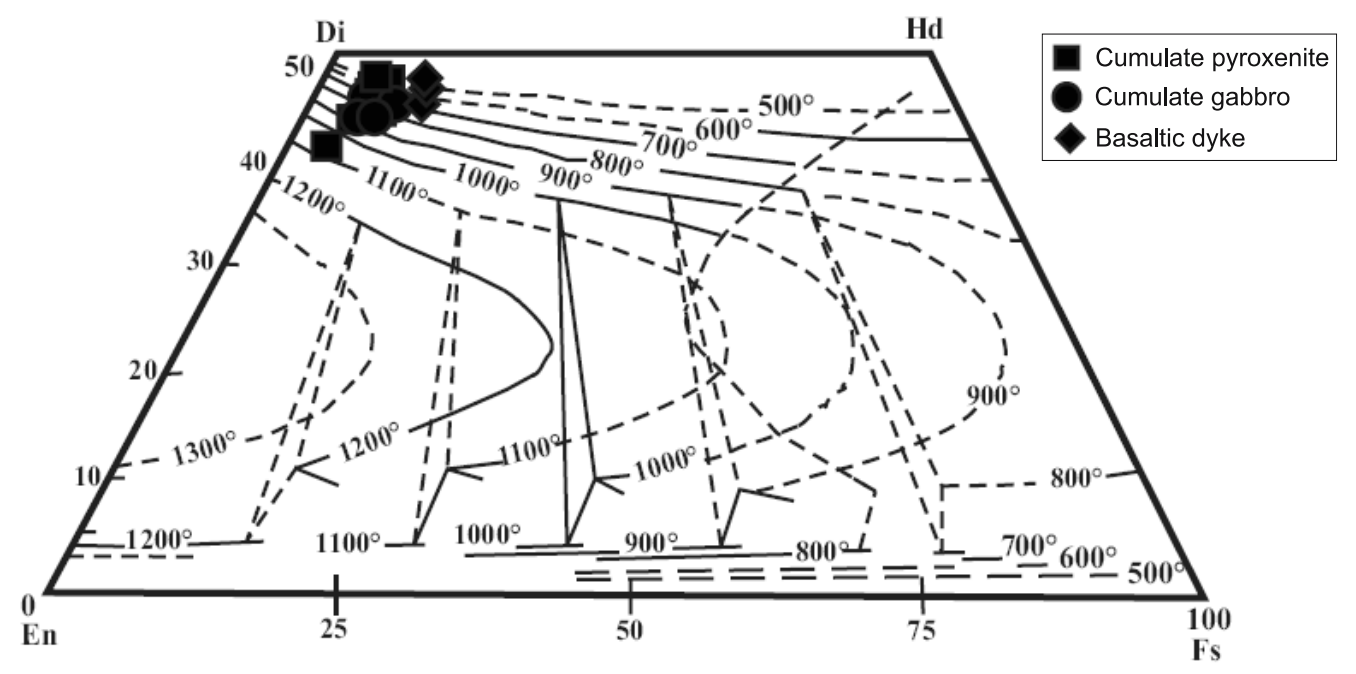

Figure 8. Projection of recalculated pyroxene compositions in Di-Hd-En-Fs diagram for thermometry (Lindsley 1983). 
Idealized ophiolite succession (Coleman 1977, from base upward)
Succession for south Andaman

Ophiolites (present study, from base upward)

\begin{tabular}{ll}
\hline (a) Metamorphic & (a) Deformed dunite \\
peridotites or mantle & (serpentinite) \\
tectonites (serpentinised) &
\end{tabular}

(b) Layered cumulate ultramafic and mafic rocks

(c) A system of vertical basic/intermediate dyke rocks (sheeted dyke complex)

(d) Submarine pillow lavas interlayered with pelagic sediments (b) Layered cumulate: pyroxenite and gabbro

(c) Basic intrusive dykes

(d) Pillow basalts (spilitic)

interlayered with arkosic wacke
Comments

The south Andaman

Ophiolite Belt stretching from Port Blair $\left(11^{\circ} 39^{\prime} \mathrm{N}\right.$ : $\left.92^{\circ} 45^{\prime} \mathrm{E}\right)$ to Chiriyatapu $\left(11^{\circ} 30^{\prime} 24^{\prime \prime} \mathrm{N}: 92^{\circ} 42^{\prime} 30^{\prime \prime} \mathrm{E}\right)$ represents an ideal ophiolite succession. This observation clearly negates the concept of dismembered Andaman ophiolite suite suggested by some previous researchers

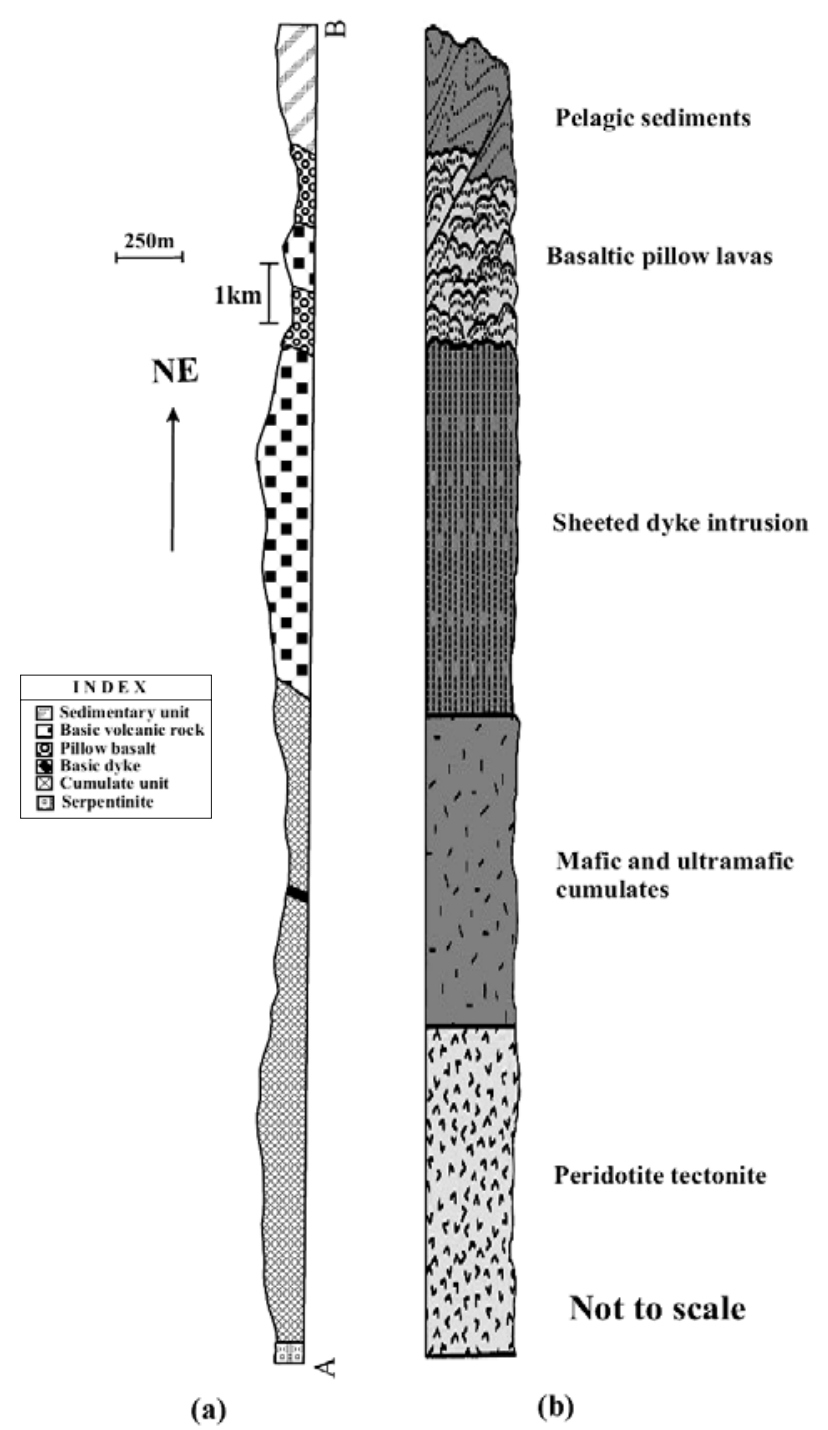

Figure 9. (a) Representative geological section (along AB) of the presently investigated ophiolite suite. (b) Vertical section of idealized ophiolite sequence (modified after Coleman 1977). have also been supported by high $\delta^{18} \mathrm{O}$ values (Nuriel et al 2009). They (Nuriel et al 2009) clearly demonstrated evidence of complete serpentinization, widespread chrysotile veining in the Troodos ophiolite complex based on their petrographic evidence and isotopic tracers $\left(\delta \mathrm{D}, \delta^{18} \mathrm{O}\right)$. This also suggests involvement of deep infiltration of sea-water during sea floor spreading which may be followed by low temperature hydration and veining. Therefore, the present article on the basis of detailed field studies (supplemented by sound petrographic and mineral chemistry data) from Port Blair $\left(11^{\circ} 39^{\prime} \mathrm{N}\right.$ : $\left.92^{\circ} 45^{\prime} \mathrm{E}\right)$ to Chiriyatapu $\left(11^{\circ} 30^{\prime} 24^{\prime \prime} \mathrm{N}\right.$ : $\left.92^{\circ} 42^{\prime} 30^{\prime \prime} \mathrm{E}\right)$ stretch of south Andaman clearly reveals preservation of complete package as has been documented from other well known ophiolite succession like Troodos Complex of Cyprus (Nuriel et al 2009). Representative geological section of the presently investigated ophiolite suite has been presented and compared with that of classical ophiolites (after Coleman 1977) (figure 9a and b). The inference derived from this comparative study brings out a close resemblance of south Andaman ophiolite sequence with idealized ophiolite succession of Coleman (1977). As a ready reckoner to the readers, the rock units of present study area have been compared with that of standard ophiolite succession (Coleman 1977).

\section{Acknowledgements}

The authors express their heartfelt thanks to Ms Sohini Ganguly, Research Scholar, Department of Geology, University of Calcutta for her encouragement, whole-hearted help and critical comments during the preparation of this paper. AS, AD and 
JR would like to acknowledge the DST-FIST for providing well-equipped microscope laboratory in the Department of Geology, University of Calcutta. The authors thankfully acknowledge Mr Sekhar Chandra Ghosh for his kind help in taking the SEM photographs. Constructive comments by two anonymous journal reviewers were very helpful to upgrade the quality of the paper. The authors wish to record their gratitude to Prof. T Ahmad, one of the Associate Editors of this journal, for his valuable suggestions.

\section{References}

Acharyya S K, Ray K K and Sengupta S 1990 Tectonics of the ophiolite belt from Naga Hills and Andaman Islands, India; Earth Planet. Sci. Lett. 99(2) 187-199.

Akihiro T and Shoji A 2006 Harzburgite dunite orthopyroxenite suite as a record of supra-subduction zone setting for the Oman ophiolite mantle; Lithos 90(1-2) $43-56$.

Arculus R J and Wills K J A 1980 The petrology of plutonic blocks and inclusions from Lesser Antilles island arc; J. Petrol. 21 743-799.

Ashchepkov I V 2009 Universe clinopyroxene barometerrecalibrations on the results of the orthopyroxene thermobarometry and experimental results and applications to clinopyroxene geotherms; Abs. EGU General Assembly 11.

Beard J S 1986 Characteristic mineralogy of arc-related cumulate gabbros: Implications for the tectonic setting of gabbroic plutons and for andesite genesis; Geology $\mathbf{1 4}$ 848-851.

Bonev N and Stampfli G 2009 Gabbro, plagiogranite and associated dykes in the supra-subduction zone Evros Ophiolites, NE Greece; Geol. Mag. 146(1) 72-91.

Clague D A 1988 Petrology of ultramafic xenoliths from Loihi Seamounts, Hawaii; J. Petrol. 29 1161-1186.

Coleman R G 1977 Ophiolites: Ancient oceanic lithosphere?; Springer-Verlag 229.

De Bari S M and Coleman R G 1989 Examination of the deep levels of an island arc: Evidence from the Tonisia ultramafic mafic assemblage, Tonisia, Alaska; J. Geophys. Res. 94 4373-4391.

Deer W A, Howie R A and Zussman J 1979 An introduction to the rock forming minerals; The English Language Book Society $528 \mathrm{p}$.

Dupuy C, Dostal J, Mercelot G, Bougault H, Joron J L and Treuil M 1982 Geochemistry of basalts from central and southern New Hebrides arcs: Implication for their source rock composition; Earth Planet. Sci. Lett. 60 $207-225$.

Escartin J, Hirth G and Evans B 1997 Effects of serpentinization on the lithospheric strength and the style of normal faulting at slow-spreading ridges; Earth Planet. Sci. Lett. 151(3-4) 181-189.

Folk R A 1968 Petrology of sedimentary rocks; Austin Tex. Hemphills, 170p.

Frey F A and Prinz M 1978 Ultramafic intrusion from San Carlos, Arizona - petrologic and geochemical data bearing on their petrogenesis; Earth Planet. Sci. Lett. 38 $129-176$.

Haldar D 1984 Some aspects of the Andaman Ophiolite Complex; Rec. Geol. Surv. India 119 1-11.
Hamilton W 1978 Tectonic map of the Indonesian region; Folio of the Indonesian Region map I-875-D, Department of the Interior, US Geological Survey.

Hebert R, Adamson A C and Komor S C 2006 Metamorphic petrology of ODP Leg 109, Hole 670A serpentinized peridotites: Serpentinization processes at a slow spreading ridge environment; Proc. Ocean Drill. Prog. Sci. Res. 106/109 103-115.

Jafri S H and Charan S N 1992 Quench textures in pillow basalt from the Andaman-Nicobar Islands, Bay of Bengal, India; Earth Planet. Sci. Lett. 101(1) 99-107.

Le Bas M J 1962 The role of aluminium in igneous clinopyroxenes with relation to their parentage; Am. J. Sci. $\mathbf{2 6 0}$ $267-288$.

Leterrier J, Mary R C, Thonon P, Girard D and Marchal M 1982 Clinopyroxene composition as a method of identification of the magmatic affinities of paleo-volcanic series; Earth Planet. Sci. Lett. 59 139-154.

Lindsley D H 1983 Pyroxene thermometry; Am. Min. 68 477-493.

Morimoto N, Fabries J, Fergoson A K, Ginzburg I V, Ross M, Seifert F A and Zussman J 1988 Nomenclature of pyroxenes; Am. Min. 73 1123-1133.

Morimoto N 1989 Nomenclature of Pyroxenes; Canad. Min. 27 143-156.

Muntener O and Manatschal G 2006 High degrees of melt extraction recorded by spinel harzburgite of the Newfoundland margin: The role of inheritance and consequences for the evolution of the southern North Atlantic; Earth Planet. Sci. Lett. 252 437-452.

Nicolas A 1989 Structures of ophiolites and dynamics of oceanic lithosphere: Petrology and structural geology; Kluwer, Dordrecht, 4.

Nuriel P, Katzi Y, Abelson M, Valley J W, Matthews A, Spieuzza M J and Ayalon A 2009 Fault-related oceanic serpentinization in the Troodos Ophiolite, Cyprus: Implications for a fossil oceanic core complex; Earth Planet. Sci. Lett. 282(1-4) 34-46.

Pal T, Chakraborty P P, Dutta Gupta T and Singh C D 2003 Geodynamic evolution of the outer-arc - forearc belt in the Andaman Islands, the central part of the BurmaJava subduction complex; Geol. Mag. 140(3) 289-307.

Pearce J A and Norry M J 1979 Petrogenetic implications of Ti, Zr, Y and Nb variations in volcanic rocks; Contrib. Mineral. Petrol. $6933-47$.

Ray K K, Sengupta S and Van den Hul H J 1988 Chemical characters of volcanic rocks from Andaman Ophiolite, India; J. Geol. Soc. London 145 392-400.

Salavati M 2008 Petrology, geochemistry and mineral chemistry of extrusive alkalic rocks of the Southern Caspian Sea Ophiolite, Northern Albroz, Iran: Evidence of alkaline magmatism in southern Eurasia; J. Appl. Sci. 8(12) $2202-2216$.

Seyler M, Lorand J P, Dick H J B and Drouin M 2007 Pervasive melt percolation reactions in ultradepleted refractory harzburgites at the Mid-Atlantic Ridge, $15^{\circ} 20^{\prime} \mathrm{N}$ : ODP Hole $1274 \mathrm{~A} ;$ Contrib. Mineral. Petrol. 153(3) 303-319.

Shastry A, Srivastava R K. Chandra R and Jenner G A 2001 Fe-Ti enriched mafic rocks from south Andaman ophiolite suite: Implication of late stage liquid immiscibility; Curr. Sci. $80453-454$.

Shastry A, Srivastava R K, Chandra R and Jenner G A 2002 Geochemical characteristics and genesis of oceanic plagiogranites associated with south Andaman ophiolite suite, India: A late stage silicate liquid immiscibility product; J. Geol. Soc. India 59 233-241.

Sisson T W and Grove T L 1993 Experimental investigation of the role of $\mathrm{H}_{2} \mathrm{O}$ in calc-alkaline differentiation and 
subduction zone magmatism; Contrib. Mineral. Petrol. $113143-166$.

Srivastava R K, Chandra R and Shastry A K 2004 HighTi type N-MORB parentage of basalts from the south Andaman ophiolite suite, India; J. Earth Syst. Sci. 113(4) 605-618.

Uysal I, Kaliwoda M, Karsli O, Tarkian M, Sadiklar M B and Ottley C J 2007 Compositional variations as a result of partial melting and melt-peridotite interaction in an upper mantle section from the Ortaca area, southwestern Turkey; The Canad. Mineral. 45(6) 1471-1493.
Vohra C P, Haldar D and Ghosh Roy A K 1989 The Andaman-Nicobar Ophiolite Complex and associated mineral resources - current appraisal; Phenerozoic Ophiolite of India, Ghose N C (ed.), Sumna Publ., Patna, 281-315.

Wilson M 1989 Igneous Petrogenesis; Unwin-Hyman Publ., London, 466p.

Xu Y, Ross J V and Mrecier J C C 1993 The upper mantle beneath the Tanlu fault, eastern China - evidence for intra-lithospheric shear zones; Tectonophys. $\mathbf{2 2 5}$ $337-360$.

MS received 1 May 2009; revised 1 February 2010; accepted 18 February 2010 